
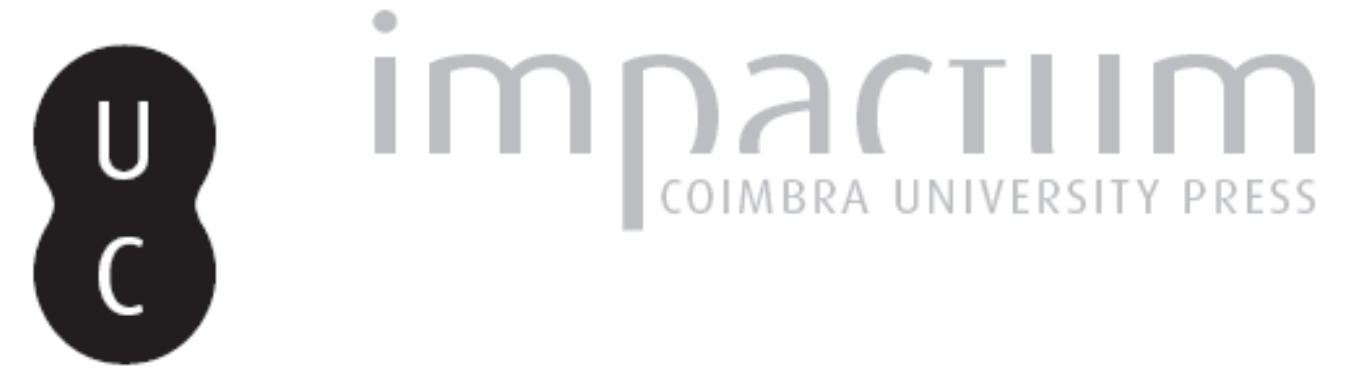

\title{
False start for the juncker recovery proposals
}

\section{Autor(es): Holland, Stuart}

Publicado por: Imprensa da Universidade de Coimbra

URL persistente:

URI:http://hdl.handle.net/10316.2/36579

DOI:

DOI:http://dx.doi.org/10.14195/2183-203X_41_2

Accessed : $\quad$ 26-Apr-2023 00:21:58

A navegação consulta e descarregamento dos títulos inseridos nas Bibliotecas Digitais UC Digitalis, UC Pombalina e UC Impactum, pressupõem a aceitação plena e sem reservas dos Termos e Condições de Uso destas Bibliotecas Digitais, disponíveis em https://digitalis.uc.pt/pt-pt/termos.

Conforme exposto nos referidos Termos e Condições de Uso, o descarregamento de títulos de acesso restrito requer uma licença válida de autorização devendo o utilizador aceder ao(s) documento(s) a partir de um endereço de IP da instituição detentora da supramencionada licença.

Ao utilizador é apenas permitido o descarregamento para uso pessoal, pelo que o emprego do(s) título(s) descarregado(s) para outro fim, designadamente comercial, carece de autorização do respetivo autor ou editor da obra.

Na medida em que todas as obras da UC Digitalis se encontram protegidas pelo Código do Direito de Autor e Direitos Conexos e demais legislação aplicável, toda a cópia, parcial ou total, deste documento, nos casos em que é legalmente admitida, deverá conter ou fazer-se acompanhar por este aviso.

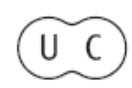




\section{N $\odot$ TASEC N}

YANIS VAROUFAKIS / STUART HOLLAND / JAMES K. GALBRAITH STUART HOLLAND MANUEL LOPES PORTO NUNO SILVA
A MODEST PROPOSAL FOR RESOLVING THE EUROZONE CRISIS

FALSE START FOR THE JUNCKER RECOVERY PROPOSALS EUROPA EM QUESTÃO: COMENTÁRIO

TIME-VARYING STOCK RETURN PREDICTABILITY:

THE EUROZONE CASE

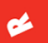

$\rightarrow$

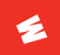

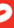

$\checkmark$

$\omega$

$\theta$

mi

-

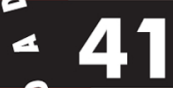
$-$

$\infty$

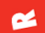
w $\Rightarrow$ $=$ $\theta$ 4

Q $\alpha$ 


\section{False Start for the Juncker Recovery Proposals}

\section{stuart Holland}

Visiting Professor at FEUC, Portugal, and Senior Research Fellow of the Institute for Social and European Studies, Köszeg, Hungary abstract

The ‘Juncker Plan' of November 2014 proposes to define investment criteria for a European Fund for Strategic Investments. This displaces that such investments are within the statutory remit of the EIF - the European Investment Fund - which is part of the European Investment Bank Group and, like the EIB, can issue bonds that do not count on national debt. The BRICS are ready to invest in $€$ bonds to promote European recovery since this is to mutual advantage in sustaining their trade. Rating agencies, pension funds and sovereign wealth funds want a European recovery. Nor are new investment criteria needed. They already were widely defined for the EIB Group by the 1994 Essen Council and in the 1997 Amsterdam Special Action Programme. A host of investment projects that already have planning approval can be jointly EIB-EIF financed and could achieve a Roosevelt style New Deal for Europe.

JEL Classification: E02, F33 
German chancellors such as Konrad Adenauer, Willy Brandt and Helmut Kohl wanted to lock Germany into a democratic Europe. Whereas Europe now is locked into a dominant German ideology of austerity. This is not helped by the German for debt - Schuld - also meaning guilt. Plus Max Weber wrongly attributing the rise capitalism to a Protestant Ethic, whereas it was the Medici and the Venetians who realised that the inverse of debt is credit and that it was credit rather than debt as bondage that enabled Europe to escape from feudalism.

Which relates to what, since Jastrow, has been known as Gestalt psychology. Such as seeing something only one-way and refusing to consider alternatives. As well as to what Melanie Klein analysed as displacement and projective identification. Such as Germany displacing Greek claims for war reparations and projecting herself as a model of economic virtue to the rest of Europe through her export surpluses and 'structural reforms'.

Denying thereby that one country's surpluses have to be others' deficits. Displacing both earlier critiques of such 'reforms' for reducing social protection, and a finding in the IMF's 2015 April World Economic Outlook that there is no evidence that such protection inhibits economic efficiency or innovation. While an IMF paper of May 2015 shows that increased public investment raises output both in the short and long term, crowds in rather than crowds out private investment, and can increase employment with limited or nil effects on public debt.

Displacing also that, while most European governments assume that they need to placate financial markets, the EU has a public non-profit credit institution whose bonds and lending for project finance do not count on national debt, nor need national guarantees nor fiscal transfers from stronger member states to others the European Investment Bank. Whereas, at a working meeting in Brussels in December 2014, neither the economic adviser to the President of the European Council, nor to Commissioner Katainen who drafted a recent proposal for a European Fund for Strategic Investment, nor the senior economist to the Commission, realised that EIB borrowing need not count on national debt nor does so for most EU member states, including Germany.

While the authority for this, as was recognised at the same meeting by Philippe Maystadt, a former president of the European Investment Bank, is the EIB itself. As I earlier learned from the EIB after a cohesion report to Jacques Delors in 1993 in which I recommended that EU bonds should be issued by a European Investment Fund-EIF to offset the deflationary debt and deficit conditions of Maastricht. And which need not count on the debt of EU member states any more than US Treasury bonds, which do not count on the debt of member states of the American Union such as California or Delaware.

\section{Misperception of the EIF}

In his adoption address to the European Parliament on July $15^{\text {th }} 2014$ Jean Claude Juncker made an EIB Group $€ 300$ billion bond funded investment programme the first of ten priorities for his Presidency of the European Commission. He had earlier been informed of the case for this at the launch of a report on Restarting Growth from the social partners Economic and Social Committee of the EU.

Yet which then got displaced by a well-intended investment recovery initiative from the Keynesian finance minister of Poland Mateusz Szczurek in an address given in September 2014 to the Brussels Bruegel Institute who proposed a new European Fund for Strategic Investments or EFSI. But on the misguided premise that this role could not be fulfilled by the European Investment Fund that I had recommended to Delors in 1993 and the European Council had set up in 1994. As Szczurek put it in claiming the need for such a new fund:

'The European Fund Strategic Investments size, its direct investment in infrastructure and long-term investing horizon would be the key differences with the existing European Investment Fund, which has only 4.5 billion euros of capital and facilitates SME's access to finance through intermediary institutions with a shorter investment horizon'. 
For example, Article 2.1 of the EIF's statutes determines that: 'The task of the Fund shall be to contribute to the pursuit of Community objectives'.

Intentionally, in my advice to Delors, this was as wide as the original open-ended remit for the EIB. There is no reference in the EIF's statutes to it being limited to financial support for SMEs.

Article 2.2 specifies that: 'The activities of the Fund may include borrowing operations'.

This enables it to undertake its own bond issues which were to have been the EU Bonds that Delors included in his December 1993 White Paper.

Both the EIB and the EIF confirmed in evidence to the Economic and Social Committee for its 2012 Own Opinion Initiative Restarting Growth that the EIF therefore could issue bonds to finance an investment-led recovery - and for a European Venture Capital Fund rather than only financial guarantees for SMEs - without a revision of its statutes or a new proposal from the Commission.

A new institution within the EIB Group such as a European Fund for Strategic Investments therefore not only is not needed but displaces that Europe already has a European Investment Fund that can realise the bond financed investment recovery to which both Mateusz Szczurek and Jean-Claude Juncker initially aspired. Which also has been submitted in a paper from the Fondation Robert Schuman in September 2014.

\section{Funding Recovery by Recycling Global Surpluses}

Further, there is no global dimension to the revised 'bondless' and thus downgraded initial Juncker and Szczurek proposals. This displaces the case for recycling global surpluses through bonds issued by the European Investment Fund, which is entirely feasible.

Thus the South African minister of finance declared at the meeting of the BRICS in Washington on September $25^{\text {th }} 2014$ that they would buy eurobonds if these were to finance a European recovery. While if the EIF were to issue bonds - or $€$ bonds as markets could quickly dub them it could do so incrementally. With a $€ 10$ billion issue in the first instance which would be likely to be over-subscribed and support the case for further issues.

Nor would this necessarily imply a major initial increase in its subscribed capital. The EIB recently gained this because of its substantial dependence on pension funds, which need AAA rating. But the BRICS do not. They need recovery of the European economy to sustain mutual trade. An increase in EIF capital from a share of unused resources in the European Stability Mechanism, has been proposed by French economy minister Emmanuel Macron. So far, has been has been blocked by Wolfgang Schäuble. But is entirely feasible since the ESM is not 'written in stone' and can undertake 'new tasks', of which increasing the capital of the EIF should be a priority.

4. Potential Support for Recovery from Rating Agencies and Bond Markets

Most EU member states fear rating agencies and have been cuttng debt and deficits to placate them. But this has displaced that when Standard \& Poor downgraded a range of Eurozone member states' debt in January 2012 it stressed that key reasons were simultaneous deleveraging of debt and spending reduction by governments and households, the weakening thereby of economic growth, and the inability of European policymakers to assure an economic recovery.

In 2013 Bill Gross, at the time head of the trillion dollar Pimco fund, also called for European recovery, stressing that funds needed growth to secure retirement income, whereas low to near zero interest rates in Europe would not. His backing for bond funded investment followed a year of inadequate performance by Pimco despite his being ranked as one of the top bond managers over the previous 15 years.

Similarly, Norway's sovereign wealth fund has cut its investments in private equity in Europe because of low growth. The Chinese $\mathrm{CIC}$ fund also made losses on its private sector investments after the onset of the financial crisis, and declared that it wanted public investment projects with a maturity of at least 10 years. 


\section{Not Needing New Criteria}

The downgraded Juncker Plan aims to set up a panel of experts to decide on investment criteria for recovery. Which is a classic case of displacement since the December 1994 Essen European Council defined these for trans-european transport and communications networks - the TENS to be co-funded by the EIB. Also since, on the initiative of António Guterres, the Amsterdam Special Action Programme of 1997 gained the agreement of the EIB that it would invest in:

- Health,

- Education,

- Urban regeneration

- Green technology and safeguarding the environment

- Finance for small and medium firms

These cover a vast range of potential investments. Urban regeneration alone can mean renovation, new building, renewal of or new public transport including trams and metro systems, electricity, gas and water supply systems etc. Investment in health can mean renovation or extension of or new hospitals and health centres. In education, the same for schools, technical colleges or universities. Without this counting on national debt.

\section{EIB-EIF Co-Finance for Recovery}

In the decade from 1997, aided by the Amsterdam Special Action Programme criteria, the EIB quadrupled its investment finance. With lack of co-finance by member states from the onset of the Eurozone crisis this then fell and put its triple AAA rating into question. Therefore the need for EIB re-capitalisation, which already has been agreed.

The EIB also has been averse to issuing eurobonds for a macroeconomic recovery programme lest it compromise the AAA rating needed by pension funds. But this is one of the reasons why I recommended the EIF to Delors and that it, rather than the EIB, should issue them to fund a recovery programme.

The EIF has next to no experience in project evaluation, but the EIB has more than half a century of experience of doing so well.

Which merits a clear distinction. With its capital increase the EIB can continue to gain pension fund finance and build on its reputation for sound project evaluation. As illustrated in Figure 1, the EIF, within its current statutes, can issue $€$ bonds attracting uninvested global surpluses from BRICS and sovereign wealth funds and co-finance investments on the range of criteria already agreed for the EIB in the Amsterdam Special Action Programme.

\section{The New Deal Precedent}

Roosevelt financed the New Deal by bonds shifting savings - high in a depression or recession into investment. It is widely overlooked that from 1933 to the onset of the war economy in the US, the federal budget deficit averaged only $3 \%$, i.e. the Maastricht limit.

In March 2014 an Initiative citoyenne européenne (ICE) published a project called NewDeal4Europe. The project anticipates project bonds of up to $€ 50$ billion per year with a multiplier of nearly 3 giving a total investment of at least 130 billion per year for 3 years 'based solely on the own resources of the Union'.

Yet the aspiration of the project that these should be 'based solely on the own resources of the Union' displaces that this is politically implausible.

Such as a financial transactions tax and a 'carbon tax', both of which are excellent proposals. Plus a new European Value Added Tax which might raise resources for investment but in the interim would further depress demand and be socially regressive. 


\section{Figure 1: Reconciling Stability and Recovery}

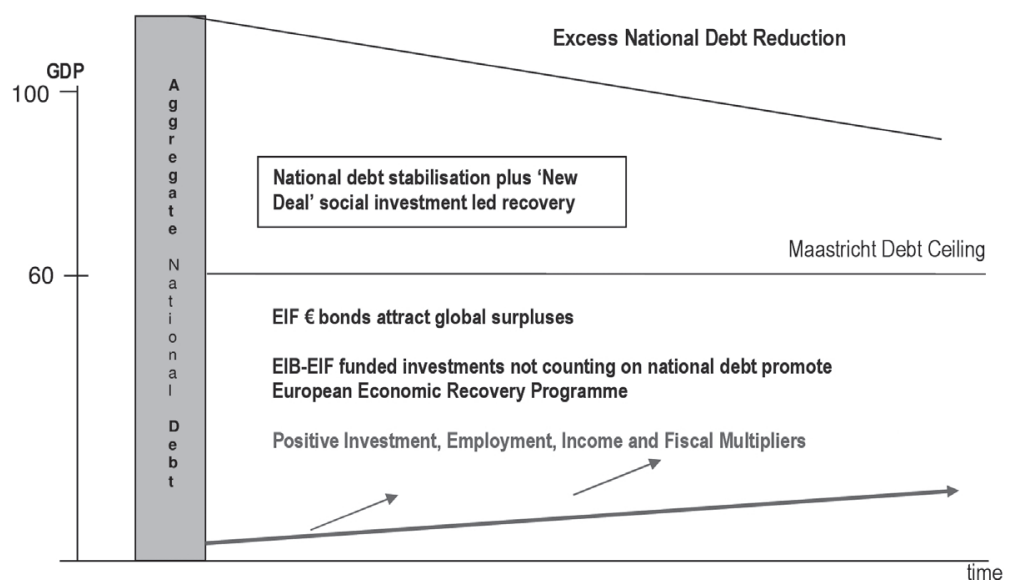

Note: A social investment led recovery programme as called for in the 2012 Economic and Social Committee Report Restarting Growth. EIB investment areas since 1997 include health, education, urban regeneration, environment, green technology and trans-european transport and communication networks. Multipliers generate higher investment, employment, income, and direct and indirect tax revenue.

All of which, if feasible at all, would take years to achieve. Whereas in the US New Deal Roosevelt did not raise taxes but shifted disposable savings into social and environmental investments. And got the programmes to initiate this deployed in its first Hundred Days.

Which the joint EIB-EIF recovery proposal also could if it were recognised that this does not need new institutions, nor new investment criteria, nor further decisions by the European Council granted its agreement to the TENS programme at Essen in 1994, and to extend the investment criteria of the EIB in 1997 through the Amsterdam Special Action Programme.

\section{Unrealistic Reliance on Private Investment}

The case for multipliers, as stressed by Mateusz Szczurek, and also by Olivier Blanchard of the IMF, is strong. But the expectation of leverage of up to 15 for private sector investment in the present form of the Junker recovery proposal - on the basis of $€ 16$ billion in rescheduled funds from the EU budget and €5 billion in guarantees from the EIB - is utterly unrealistic.

Private sector investment in Europe is a sixth below its pre-crisis levels. Firms simply will wait to see if a medium-term recovery occurs and their spare capacity met before they undertake net investment on a major scale. Guarantees against losses for only some projects will not change this.

Besides which, unlike the claim of Thomas Piketty that the Asian economies have benefited far more from open markets than from foreign direct investment, where leading European firms for decades have been investing on a major scale has not been in Europe but in Asia. For example, half of China's exports have been from foreign direct investment by European, US, Japanese and Taiwanese multinationals.

\section{Gaining Recovery}

What is needed to achieve a 'New Deal for Europe' are not debilitating 'structural reforms' or competing-unto-death but the social and environmental investments such as those of the 
Roosevelt New Deal which recovered confidence of the public and the private sector and which could be deployed from now within the investment criteria of the 1994 Essen TENS programme and the 1997 Amsterdam Special Action Programme.

There has been concern that a bond funded investment-led recovery would take longer than the three years of the November 2014 Juncker recovery target. This also was claimed by DG Economy and Finance as an objection to the Delors December 1993 Union Bond proposal. But before Delors retired, I encouraged a trawl by his cabinet of national investment projects that had planning approval but been postponed since agreement of the Maastricht criteria and which revealed that these already totalled 750 billion ecu.

In parallel, the proposal for an EFSI has prompted governments to forward $€ 1.1$ trillion of as yet unfunded projects. Yet which are likely to remain unrealised if the EFSI expects a leverage of 15 rather than bond finance. Whereas, if co-funded by EIB and EIF bonds the investment multipliers in realising them - on the basis of previous EIB projects - would be between 2.5 and 3.0.

This co-finance not only need not count on national debt and therefore not be constrained by the Maastricht $60 \%$ national debt limit. With investment in EIB bonds by global pension funds and EIF bonds by sovereign wealth funds it could deliver a sustained recovery of investment, jobs and income in the European economy. Which, like the Roosevelt New Deal on which the original proposal to Delors for EU bonds was based, could restore confidence not only in the private sector but also the conviction that governments can govern rather than rating agencies rule.

\section{References}

Abiad, A.; Furceri, D.; Topalova, P. (2015) The macroeconomic effects of public investment: evidence from advanced economies. IMF Working Paper WP/15/95.

Blanchard, O.; Leigh, D. (2012) IMF: World Economic Outlook.

Blanchard, O.; Leigh, D. (2013) Growth Forecast Errors and Fiscal Multipliers. IMF Working Paper/13/1.

Delors White Paper (1993). Growth, Competitiveness, Employment: The challenges and ways forward into the 21st century. European Commission. COM (1993) 700. December.

Economic and Social Committee (2012) Restarting Growth: Two Innovative Proposals. ces474-2012_ac en and also in ten other EU languages.

European Commission (2014). An Investment Plan for Europe. COM (2014) 903 November (the revised and downgraded initial Juncker Plan).

De Witte, B. (2012) The European Stability Mechanism and Treaty on Stability, Coordination and Governance: Role of the EU Institutions and Consistency with the EU Legal Order. European Parliament.

Fabre, F.; Cazanave, F.; Billion, J-F. (2014) Les Limites du Plan Juncker d'Investissements de I'Union Européenne et les Supériorités de l'ICE «NewDeal4Europe» en Matière de Ressources Propres de l'Union Européenne. Le Taurillon, September $15^{\text {th }}$.

Fondation Robert Schuman (2014) Pour une Relance de l'investissement en Europe. September $22^{\text {nd }}$.

Holland, S. (1993) The European Imperative. Foreword Jacques Delors. Nottingham: Spokesman Books.

Holland, S. (2014) Europe in Question - and what to do about it. Nottingham: Spokesman Books.

Jastrow, J. (1899) The Mind's Eye. Popular Science Monthly, 54, 299-312.

Klein, M. (1961) Developments in Psychoanalysis. London: Hogarth.

Piketty, T. (2013) Le Capital au XXIe siècle. Paris: Seuil. (2014). Capital in the $21^{\text {st }}$ Century, Cambridge MA: Belknap Press.

Rocard, M. (2014) Préface de la Modeste Proposition pour Résoudre la Crise Euro. Paris: Veblen Institute.

Szczurek, M. (2014) Investing for Europe's Future. Address to the Bruegel Institute. Brussels: September $4^{\text {th }}$. http://www.bruegel.org 